\title{
中性抄紙におけるウエットエンド薬品システム*
}

BASF ジャパン株式会社 製紙薬品営業 岡 田 憲 幸

\section{System of Wet-end Chemicals for Neutral Papermaking}

\section{Noriyuki Okada}

Sales/Paper Chemicals, BASF Japan Ltd.

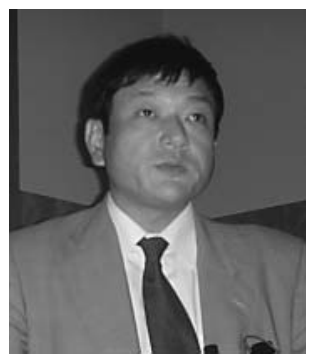

Neutral papermaking tends to increase. Increase of $\mathrm{pH}$ involves adverse affects such as drop of size degree, increment of foam in white-water or increase of pitch problem. Therefore, existing chemicals for acid papermaking must be reviewed to redesign optimized system of wet-end chemicals for neutral papermaking.

Innovative wet-end sizing agent "PMD", originative retention/drainage system and effective fixation system are introduced for neutral papermaking in this report.

分類： $\mathrm{W}_{5}$ サイズ剤, $\mathrm{Y}_{5}$ 高分子化学

\section{1.はじめに}

\section{1 中性抄紙化の要請}

昨今, 中性抄紙が増えてきている。例えば，新聞用 紙では，カラー印刷に高度に対応するための高白色度 化, 軽量紙に対応するための不透明度の向上が求めら れている。それに伴い, 填料として安価で不透明性・ 平滑性に優れる炭酸カルシウムを使用した新聞用紙の 抄造が有効である。しかし炭酸カルシウムは酸性雲囲 気下で操業性や紙の品質の低下を伴う炭酸ガスを発生 するので, 炭酸カルシウムを填料として使用するため には，従来酸性条件の下で行われていた抄造を中性条 件下で行う必要がある。

また, 中性抄紙が増え中性の古紙が多く流通し,さ らには資源リサイクルの促進とコスト削減を実現する 古紙配合率の上昇傾向と相まって, 抄紙 $\mathrm{pH}$ の上昇に 拍車がかかってきている。

*平成 17 年度年次大会講演（講演 No. C 10）
1.2 中性条件下でのウエットエンド薬品の見直し 抄紙 $\mathrm{pH}$ の上昇は, サイズ性や歩留りの低下, 白水 の泡やピッチの増加といった悪影響を伴い, 従来硫酸 バンドに頼っていたウエットエンド薬品を見直し, 中 性抄造条件に最適化した薬品システムを新たに構築す る必要がある。

この報告では, BASF の欧米での豊富な中性抄造用 薬品の開発や応用の経験を基に, 中性条件で最適なウ エットエンド薬品システムを紹介する。

\section{2. 中性抄紙条件下での内添サイズ剂の選定}

\section{1 中性抄紙化のサイズ性に対する悪影響}

酸性条件下での抄造では, ロジン系のサイズ剤が古 典的に使用されており, 安価に高サイズ度が得られる。 しかし，ロジン系のサイズ剤は，そのサイズ性の発現 機構によりアルミニウムイオンの存在が不可欠で, 硫 酸バンドを添加しない, あるいは添加を削減する中性 抄紙においては，サイズ性の低下は免れない（図 1)。 必要なサイズ度を出すためには多量のロジンサイズ 


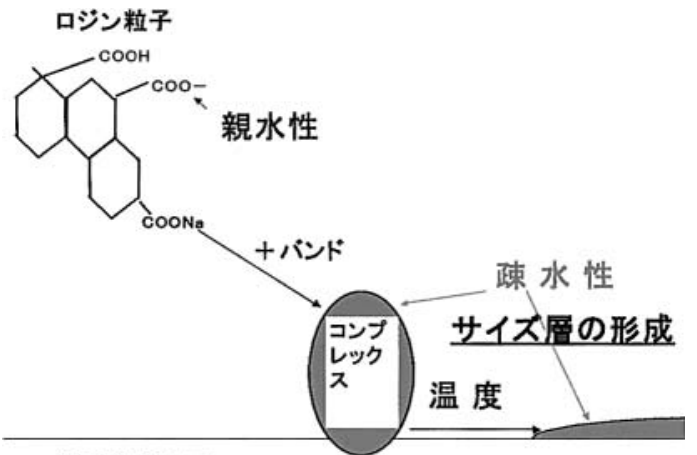

纎維 表 面

図 1 ロジン系サイズ剂のサイズ性発現機構

剂を添加する必要があり，サイズ剂のコスト高と，サ イズ剤の高濃度添加に起因する発泡による操業性の低 下や消泡剂のコスト増の問題を抱える。

\section{2 中性サイズ剂の使用}

本来は酸性条件下で使用するロジン系サイズ剂に替 わり，中性抄紙条件下では中性サイズ剤を使用するの が有効である。

$\mathrm{AKD}$ は古くから中性条件下で有効なサイズ剤とし て知られている。AKD はそのサイズ性の発現機構か ら硫酸バンドの添加を必須とせず，中性条件下におい ても高度のサイズ効果を発現することが可能である (図 2)。

しかし，AKD はその定着率が低く，また未定着の AKD は加水分解しやすい。この加水分解物が原因で マシンが污れやすく，また紙表面の摩擦係数の低下す なわち滑りの問題を伴うといった弱点を有する。

\subsection{AKD ディスパージョンの改良}

AKD が有するマシン污れや紙表面の滑りの問題を 解決するためには，AKDの定着率を向上させなけれ
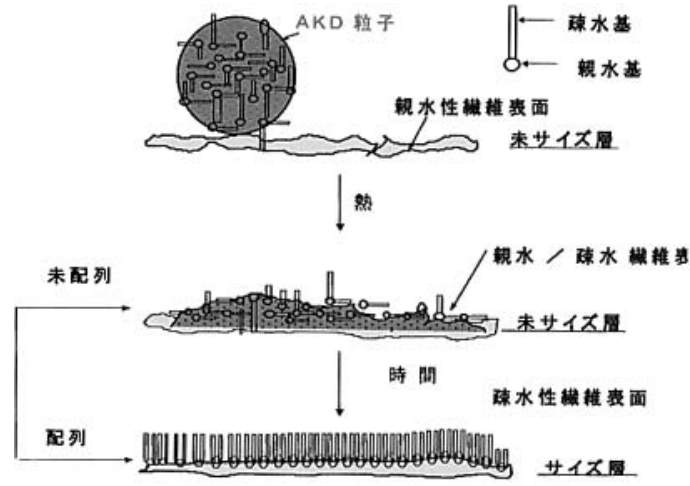

図 $2 \mathrm{AKD}$ サイズ剤のサイズ性発現機構
ばいけない。そのために，従来保護コロイドとして使 用していたカチオン改質澱粉に替わり，強カチオン性 のポリマーを保護コロイドとして使用する製品もある が, サイズ剤の歩留り率は改善されるものの, 凝集の 問題や蛍光増白剂と併用しにくいといった欠点も併せ 持つ（図 3)。

BASF は，これらの問題を解決するため，AKD デ イスパージョンに適切な保護コロイドを採用すること に成功した。

2.4 新規の保護コロイドを採用する AKD 系サイ ズ斉—PMD（Polymer Modified Diketen）

$\mathrm{PMD}$ は AKD 粒子をカチオン化澱粉とカチオン性 の特殊な合成高分子の混合物から成る保護コロイドで 包まれている構造をもつディスパージョンである（図 4)。この混合保護コロイドの相互作用により, AKD 粒子同士がネットワークを形成し，ディスパージョン の安定性が向上するとともに，AKDの歩留りが向上 している(図 5)。

一般的な AKDの定着率は, 繊維への反応定着と填 料添加率に比例して得られる填料への定着の合算から

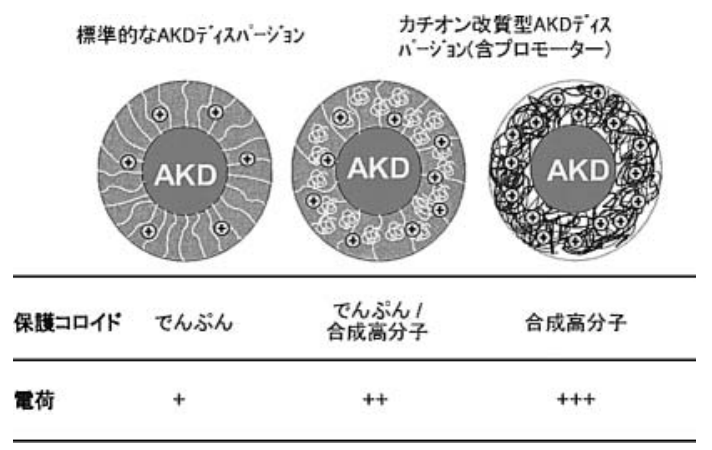

図 3 従来型の $\mathrm{AKD}$ ディスパージョンの保護 コロイド

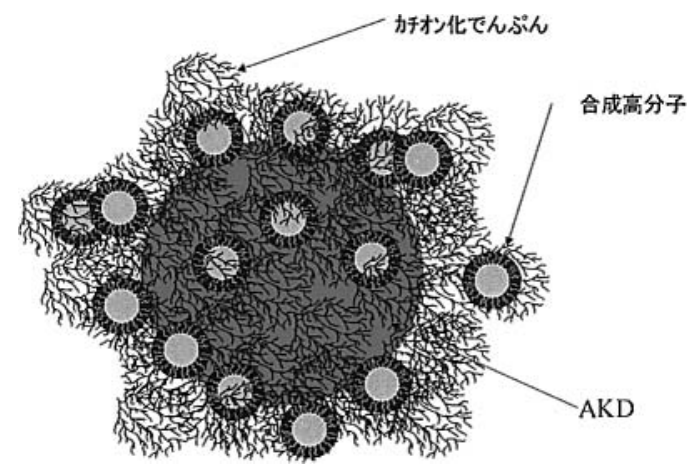

図 4 PMD の構造 


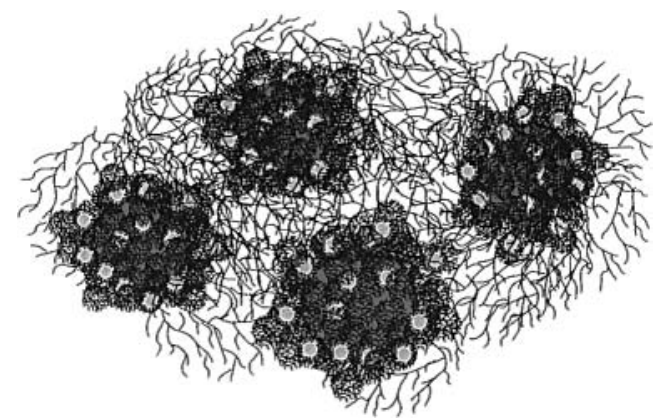

図 5 PMD のネットワーク

求められ, その定着率はけして高くないが, PMDの ネットワークによる定着が，従来の製品の定着率を大 幅に底上げするように作用し，高い定着率を実現する （図 6)。これにより，未定着物の加水分解に起因する マシン污れや紙の滑りの問題を解決するとともに, 消 泡剤の削減も図られる。またPMDに使用されている 特殊高分子はカチオン性が比較的弱く, 蛍光増白剤な どのアニオン性の添加剤に悪影響を与えない。

\section{$2.5 \mathrm{PMD}$ の実施例}

中性条件下での新聞抄紙における実施例を示す（図 7)。この例では, 従来中性ロジンを使用しており, こ

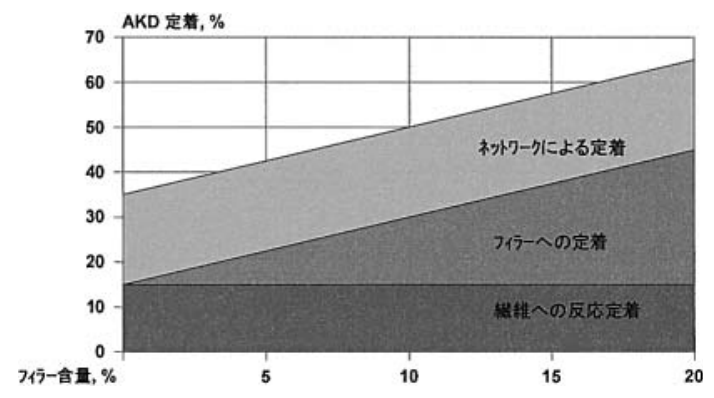

図 6 PMD ネットワークによる定着率の向上

\section{$\mathrm{pH}=6.7$}

サイズ度(Water drop) $80 \pm 20 \mathrm{sec}$

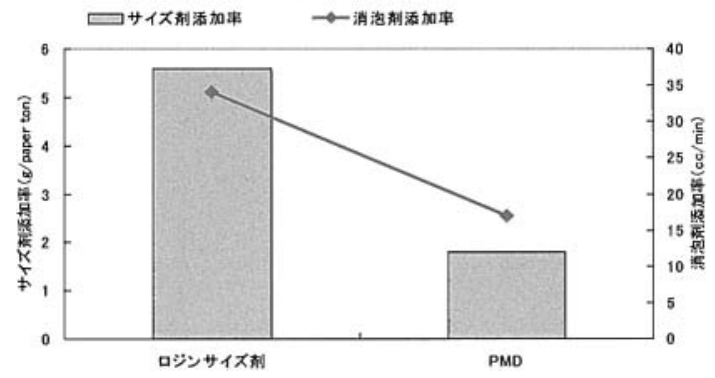

図 7 ロジンサイズ剤と PMD の比較（実施例）
れをPMD で代替した。サイズ度を一定に保ち，ロジ ンサイズ剤をPMD におき替えたところ, サイズ剤の 添加率が大幅に減少するとともに, 消泡剂の添加率も 減っている。 また, 摩擦係数の変化も無く, 顕著な マシン污れの発生の報告も無かった。

\section{3. 中性抄紙条件下での歩留り・ろ水剂の選定}

\section{1 中性抄紙条件下での歩留り・ろ水剂システムの 多梯性}

紙料の歩留りやワイヤーでの水切れを最適化するこ とは, 製造コスト, 操業性および紙の品質を維持向上 する上で不可欠である。この最適化に寄与する薬剤が 歩留り・ 水剂である。歩留り・ 水剂を大別すると, 巨大分子量のポリマーと繊維との分子間吸引力で凝集 を起すタイプのものと, 強いカチオン電荷を帯びたポ リマーと繊維間の電気的吸引力により凝集をおこす夕 イプのものがある。

酸性抄紙条件下では, 電気的吸引力で繊維を凝集さ せる種類のカチオン性ポリマーは歩留り・ろ水剤とし ての機能を発揮しにくい。酸性条件下では主に分子間 吸引力で凝集を起す高分子量のポリアクリルアミド (PAM) が歩留り・ろ水剂システムの中心をなす。

しかし, 抄紙条件を中性にすると, 電気的吸引力を 利用する高カチオン性ポリマーがその機能を発揮し, 各々のカチオン性ポリマーに特徴的な効果を得ること ができ, 多様なニーズに対応できる歩留り・ろ水シス テムを構築することが可能となる。

\section{2 歩留り・ろ水剂に使用する高カチオン性 ポリマー}

電気的吸引力を利用して凝集を起させるには，ある 程度カチオン電荷密度が高いことが要求される。 BASF ではこの要求に応えるため, ポリエチレンイミ ン（PEI）を提供している。

PEI を歩留り・ろ水剂として応用した場合, 形成さ れるフロックは，その凝集機構により，小さく密集し たもので搾水性に優れ，またシェアーに強く，さらに， たとえ一度プロックが壊れたとしても再凝集しやすい (図 8, 図 9)。

PEI 単体でも歩留り・ろ水剂として十分機能を発揮 し得るが，他の薬剤と組み合わせることにより様々な ニーズに対応する多様な歩留り・ろ水システムを構築 することができる。PEI とポリアクリルアミド(PAM) を組み合わせたポリミックスシステムがその一例であ る。ポリミックスシステムを利用した場合のフロック の特徴は, PEI に特徴的な小さなフロックが PAMの 作用により大きな凝集を形成することにある。これに 


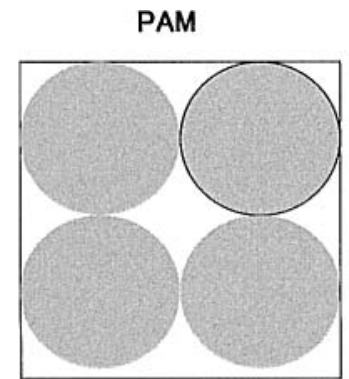

PEI

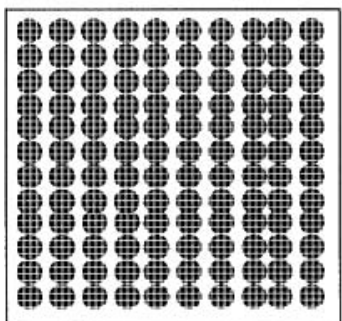

\section{PAM+PEI}

フロックが大きい

ろ水性良好

䆛水性は悪い

シェアに弱い

地合が悪い

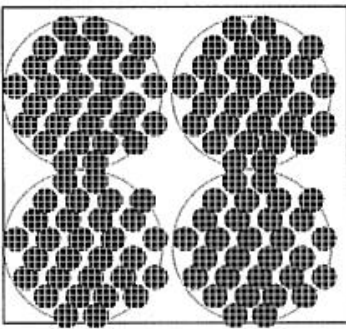

大きいフロックの中で小さい

フロックを形成

\section{フロックが小さい}

ろ水性はややPAMに劣る

窝水性は良好

シェアに強い

地合が良い
万水性良好

窝水性は良好

地合はPAMより良い

シェアに強い。

図 8 PAM, PEI および PAM と PEI 併用の場合のフロックの違い

PAM

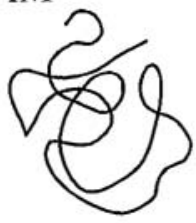

PEI

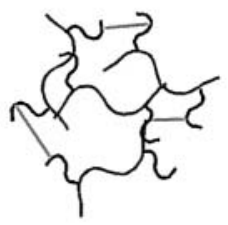

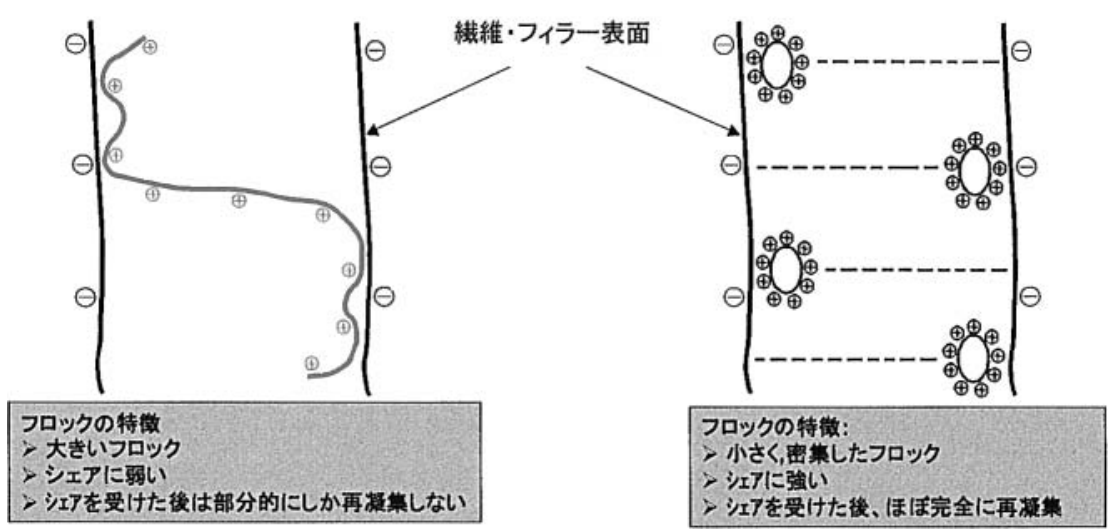

図 9 PAM と PEI のフロック形成のメカニズム

より，PAM の特徴である，ろ水性の良さを残しつつ， PEIの特徴である搾水性が優れ, シェアーに強いフロ ックになり, またPAM 単独の場合に比べて地合いも 良好になる（図 10）。

\section{3 ポリミックスシステムの実施例}

この実施例では, 中性抄造条件で中質印刷用紙を抄 紙しているマシンで，抄速を向上し操業性を改善する ことを目的にポリミックスシステムの導入を行った。 従来はPAM のみを歩留り・ろ水剂として使用してい 


\section{PEI + カチオンPAM}

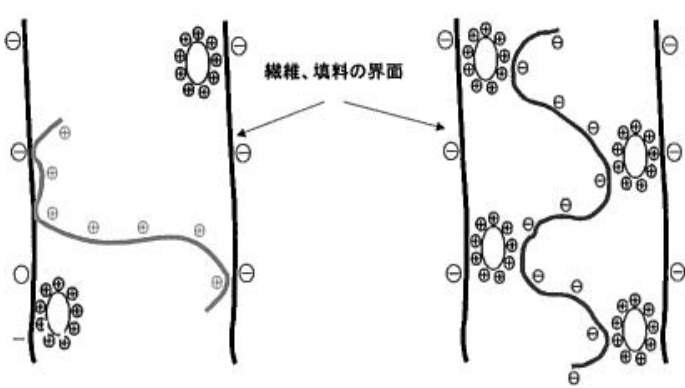

図 10 ポリミックスシステムのフロック形成の メカニズム

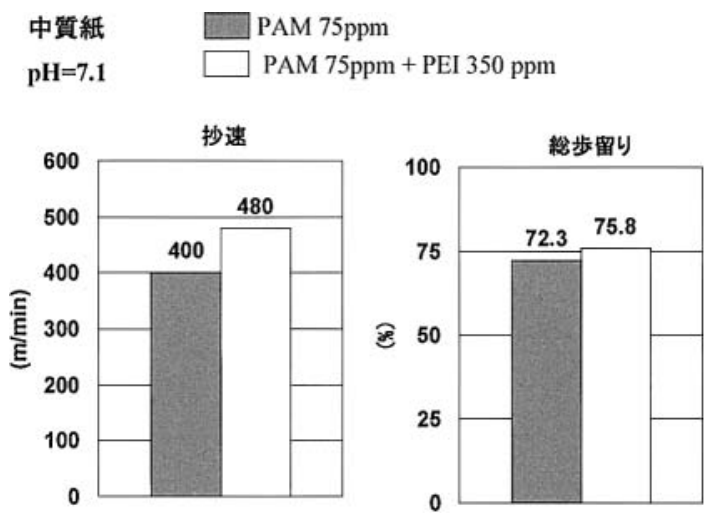

図 11 ポリミックスシステムの実施例

たが，思うような抄速が得られていなかった。PAM に加え，PEI を併用することにより大幅に抄速の向上 が図られ, 総歩留りも改善され, 大きなメリットが得 られた（図 11）。

\section{4. 中性抄造条件下での定着剂の選定}

\section{1 中性抄紙化によるピッチ問題に対する影響}

抄紙条件を酸性から中性にすると, 硫酸バンドの添 加量が大幅に削減される。

しかし硫酸バンドの添加量の減少は, それまで硫酸 バンドに頼っていた，アニオン性製紙阻害物質の定着 が不十分になり系内に蓄積し，ろ水性の低下，パルプ や填料あるいは各種薬品の歩留りの低下, デポジット の発生などの弊害を誘発する。

\section{2 硫酸バンドの代替物質の必要性}

アニオン性製紙阻害物質は, 緘維に定着させ, 紙と して系外に排出し, 紙料中の量を一定以下に保たなけ れば既述の問題が発生する。
表 1 定着剤として使用されるカチオン性ポリマー

\begin{tabular}{c|c|c}
\hline $\begin{array}{c}\text { 分子量 } \\
\left(\mathrm{g} / \mathrm{mol} \times 10^{6}\right)\end{array}$ & Polymer & $\begin{array}{c}\text { 電荷密度 } \\
(\mathrm{meq} / \mathrm{g})\end{array}$ \\
\hline $0.2-0.3$ & ポリダドマック & $\sim 6$ \\
\hline$<0.05$ & ジシアンジアミド & $3-4$ \\
\hline $1-3$ & ポリアクリアマイド & $1-4$ \\
\hline $0.05-0.2$ & ポリアミン & 6 \\
\hline 1.0 & 変性ポリエチレンイミン & $11^{*}$ \\
\hline $0.1-5$ & ポリピニアルミン & $0-15^{*}$ \\
\hline
\end{tabular}

従来は硫酸バンドがその定着剤としての機能を発揮 していたが，中性条件下においては他の薬剤に代替す る必要があり, 各種のカチオン性ポリマーがそれを担 う(表 1)。

\subsection{BASF が推奨する定着剂}

定着剂として使用されているカチオン性ポリマーは それぞれ固有の分子量とカチオン電荷密度を有してお り，定着効果に関係している。

定着剂の定着機構は，アニオン性の阻害物質と定着 剤が電気的に結合し，これが更にパルプ纎維に結合す ることによる。その結果，紙料中に浮遊する阻害物質 が紙に抄きこまれ，紙として系外に排出される。この 際, 定着剤のカチオンの電荷密度が小さいと, アニオ ン性阻害物質と定着剂が接触した段階で, 定着剂のカ チオン電荷がすべて中和され, 繊維に電気的に結合で きなくなる。従って, 定着剤には, ある程度強いカチ オン電荷を持ったものが要求される（図 12）。

BASFでは, 上述の理由により, カチオン性ポリマ 一の中でも最もカチオン電荷の高いポリエチレンイミ ン (PEI), あるいはポリビニルアミン (PVAm) を 定着剂として推奖している。

\section{$4.4 \mathrm{PEI}$ を定着剂に使用した実施例}

原料構成を DIP, TMP，GP とする中性新聞抄紙で, DIP，TMP，GP それぞれに固形分で $175 \mathrm{ppm} の \mathrm{PEI}$ を添加し, ピッチの個数をへマシトメーターで計測し た。その結果，各原料のピッチの個数が減少しており， その結果種箱や白水のピッチの個数も減少し, 定着剂 によって系内が浄化されているのがわかる（図 13）。

最適な定着剂を選定するテーブル試験結果の一例を 示す。レーザーピッチカウンターを使用し, 現行の定 着剂 A と PEI の定着効果を比較している。定着剂 $\mathrm{A}$ を添加したものは, ピッチの個数が減少しており一見 定着効果が充分に現れているように見えるが，粒子径 


\begin{tabular}{|c|c|}
\hline 岡 & 月 \\
\hline
\end{tabular}

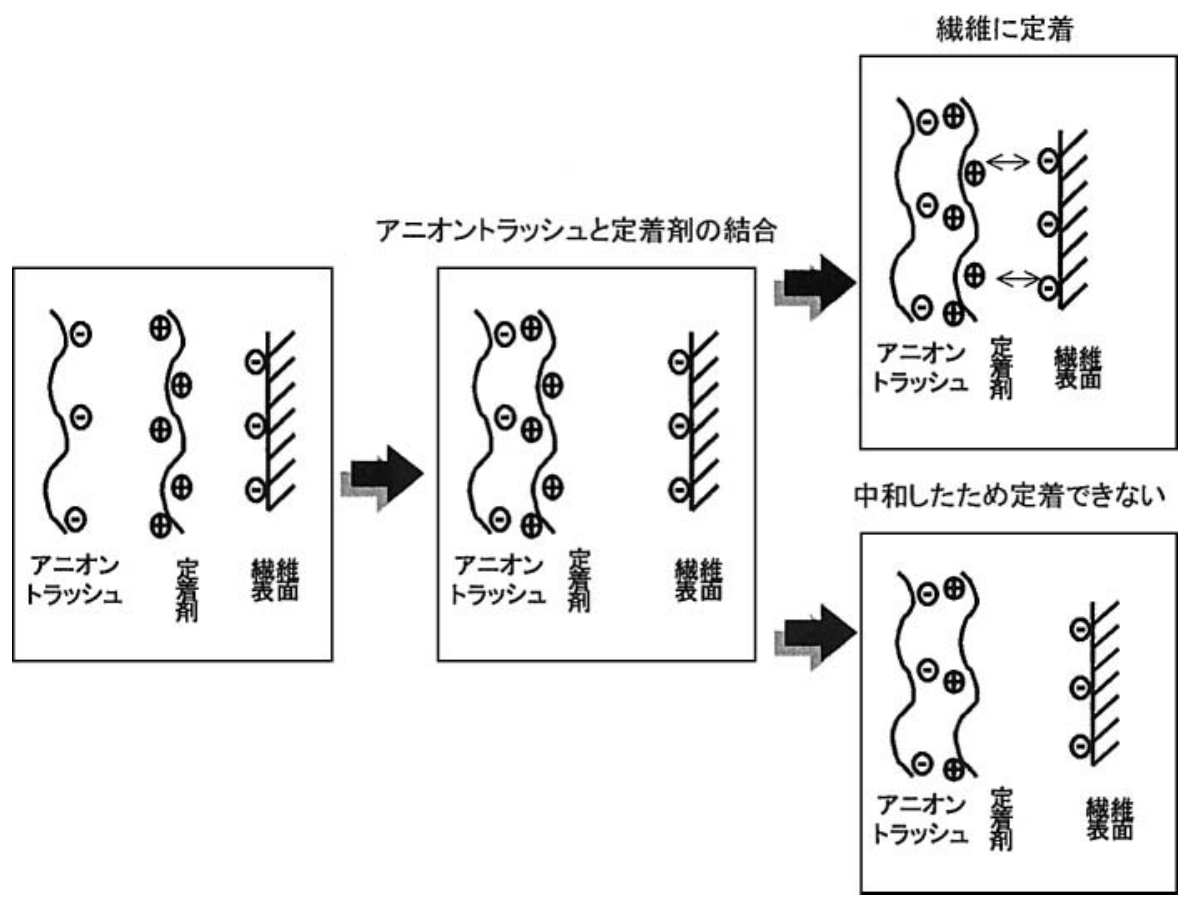

図 12 定着のメカニズム

坪量 $45 \mathrm{~g} / \mathrm{m}^{2}$,紙中灰分 $11-12 \%, \mathrm{pH} 7.0$ (バンド)

\section{$60 \%$ DIP / 30\%TMP / 10\%GP}

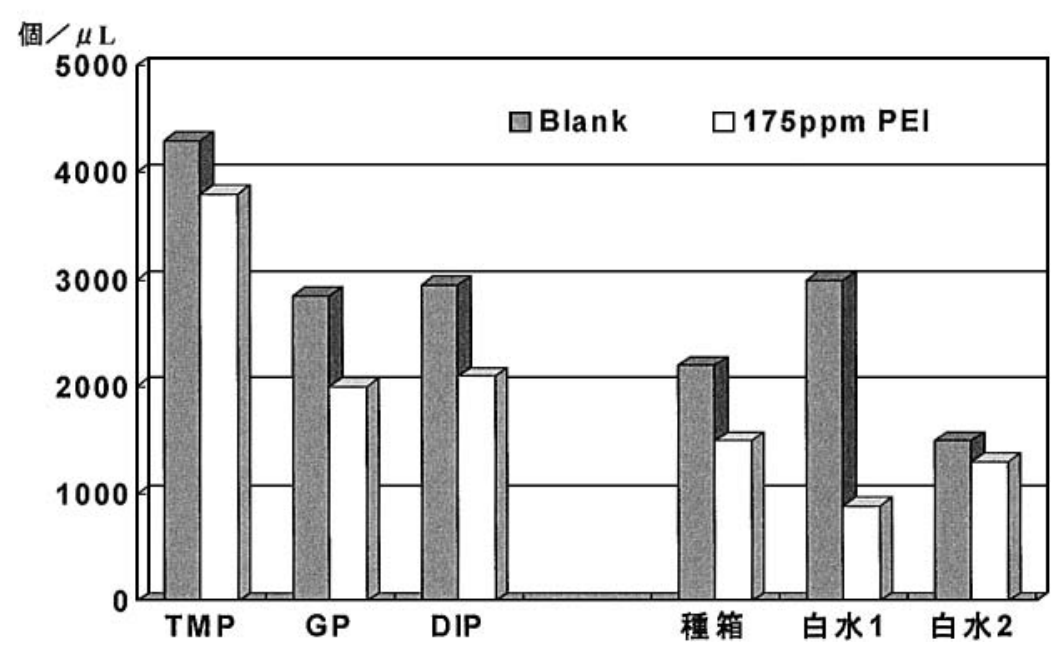

図 13 PEI を定着剂として使用した実施例

が大きくなっており，ピッチ同士の凝集が起るだけで， なく粒子数が減少しており，定着剤によってピッチが 繊維に充分定着していないと推測される。それに対し＼cjkstart瀻維に効果的に定着している様子がわかる（図 14）。 て, PEIを添加したものは, 粒子径が大きくなること 


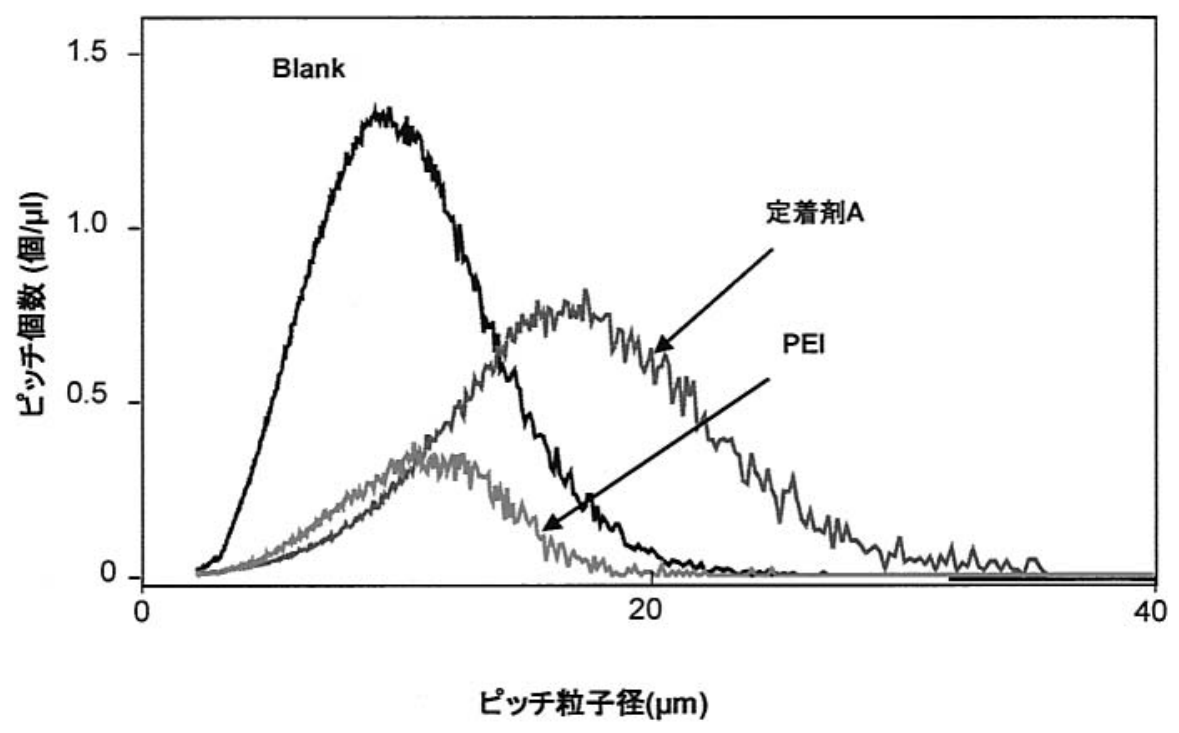

図 14 ピッチ粒度分布測定結果

\section{5. 最 後に}

抄紙 $\mathrm{pH}$ の中性化は, 時代の流れであり社会的要請 でもある。それに伴い, ウエットエンド薬品の選定も 的確に行わなければならない。それには，酸性条件下 で使用していた個々の薬品の代替品を単に当てはめる
のではなく, ウエットエンド薬品をシステマチックに 再設計する必要がある。

紙の品質や操業性の追求は, 個々の薬品の機能が発 揮されるだけでは達成されない。薬品同士の相互作用 や相乗効果を的確に予測し, マシンとの相性も把握し た上で総合的に判断しなければならない。 